Rev. Ter. Ocup. Univ. São Paulo, v. 20, n. 3, p. i. set./dez. 2009.

\title{
Editorial
}

\section{PACTO: 10 anos de encontros, pesquisa e produção na interface das artes e da saúde}

Em 1998, os primeiros grupos do Programa Permanente de Composições Artísticas e Terapia Ocupacional (PACTO) recebiam pessoas da comunidade, usuários ou não de serviços de saúde, com interesse em atividades artísticas, plásticas e corporais. A concepção, implantação, desenvolvimento e sustentação coletiva deste programa na Universidade de São Paulo foram marcados pelas dimensões materiais e sensíveis da existência de populações que vivem à margem de processos socioculturais. Articulando ensino, pesquisa e extensão universitária, o PACTO teve, desde então, o objetivo de favorecer aos seus participantes a oportunidade de desenvolver potenciais criativo, artístico e intelectual ao acompanhá-los em atividades grupais e ao viabilizar-lhes o acesso a eventos culturais. Gradativamente, a experiência desdobrou-se em múltiplas ações e deu lugar a novas composições num campo de interface entre as artes e a saúde, constituído no enfrentamento com um território cultural dominado por lógicas de consumo excludentes de outras linguagens e outras formas de expressão e, paradoxalmente, interessado em abranger alteridades.

Dez anos de atividade de um programa didático-assistencial no âmbito da Universidade de São Paulo mereceu uma comemoração. Assim, em 2008, a equipe do Laboratório de Estudos e Pesquisa Arte, Corpo e Terapia Ocupacional organizou um evento em que foi possível compartilhar a história deste programa e sua proposta de trabalho, revisitando-a e atualizando as diferentes ações produzidas neste período com a equipe, seus parceiros, estudantes e população atendida. $\mathrm{O}$ evento trouxe consigo a necessidade de partilhar e ampliar a visibilidade destas experiências no âmbito da formação na graduação e pós-graduação, na atenção às pessoas e na produção de práticas e saberes. Notou-se que estas ações produziam uma contribuição para a Terapia Ocupacional e outras áreas da saúde, das artes e da educação e era preciso colocá-las numa rede maior de contatos e trocas para a produção de conhecimento, dando-lhe publicidade e verificando sua possibilidade de agregar novos valores. Disto decorreu a produção deste conjunto de escritos, acolhidos numa edição temática da Revista de Terapia Ocupacional da Universidade de São Paulo.

A realização de uma produção compartilhada dos textos e a construção desta edição demandou a articulação de diferentes campos de conhecimento, com suas respectivas linguagens, além de uma composição de variados modos de escrever e conceituar as experiências coletivas, que contassem alguns traços desta história, construída num cotidiano de resistência e criação.

Os textos aqui presentes relacionam-se às temáticas da produção de saúde e subjetividades no mundo contemporâneo, a partir das experiências do PACTO, considerando que é fundamental dar tempo e espaço para que várias formas de fazer, expressar, inventar e conhecer possam ser acolhidas, numa perspectiva na qual a medida humana se apresente em sua heterogeneidade.

Evidentemente, muitas experiências e composições não puderam ser contempladas, divulgadas ou traduzidas nesta edição. Isto não significa que foram experiências menos importantes, ao contrário. São formas e acontecimentos produzidos que apresentam uma materialidade efêmera, cujo registro e apresentação só podem se dar através de outra forma de estruturar a linguagem, marginal aos registros verbais. Para sua expressão, elas necessitam de grafismos, de filmagens, da escuta de sonoridades diversas, da performance, enfim, de suportes porosos que prosseguiremos buscando para outras possibilidades de divulgação.

Assim, os textos aqui presentes são cartografias de alguns processos da trajetória viva do PACTO, espécies de fotografias daquilo que vibra para a emergência de novas camadas de produção de saberes e de práticas. O compromisso que prepondera na exposição destas experiências é o de estabelecer um ambiente formativo, a partir do qual se tecem novas relações com o mundo, com suas formas de poder e com os modos de compreender e de viver.

Consonantes aos propósitos do PACTO, os escritos desta edição evidenciam um espaço de realizações e virtualidades em que forças produtivas tornam-se disponíveis e potencializam ações humanas para o enfrentamento conjunto das marginalizações opressivas, do isolamento, da impossibilidade do fazer, e das inevitáveis angústias que disto decorrem. Ao oferecer instrumentos conceituais para este embate, torna-se possível habitar, em alguma medida, os lugares da cultura, da linguagem, da criação, da pesquisa, da re-invenção do ambiente, e assim enriquecem-se os modos de vida e de sensibilidade daqueles que se acercam deste programa.

Andréa do Amparo Carotta de Angelli,

Eliane Dias de Castro

Elizabeth Maria Freire de Araújo Lima Erika Alvarez Inforsato 